\title{
Studies on Body Water in Man
}

\section{Total Body Water in Normal Subjects and Edematous Patients}

(Directed by Assistant-Professor, K. Itahara)

By

\section{Denjiro Musha}

(武者 傳治郎)

From the Medical Clinic of Prof. F. Nakazawa, Tohoku University, Sendai

(Received for publication, April 19, 1955)

Body water occupies about $70 \%{ }^{1 \prime}$ of body weight and is the greatest component of the living organism. All activities of every cell proceed in the medium of "body water", which is considered as the basis of metabolism. Edema and dehydration, the most important of all clinical problems, represent abnormal accumulation and loss of water in tissues, respectively. In consideration of the importance of body water, methods for its measurement have been studied. The first estimate of body water content was accomplished by desiccation of cadavers. By the desiccation procedure Bischoff ${ }^{2}$ ) reported in 1863 that the total body water in man was $58.5 \%$, and recently Mitchell ${ }^{13}$ reported that it was $67.8 \%$ of the body weight. But this procedure cannot be employed in living subjects. A satisfactory method for the measurement of the total body water in vivo

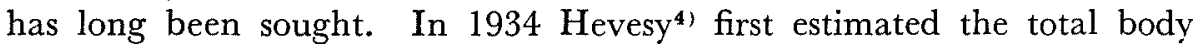
water in living man by use of heavy water (deuterium oxide). Heavy water is an ideal substance for the measurement of the total body water, but the costliness of the substance and the complicated apparatus for its measurement make its use inconvenient. Potassium, ${ }^{5)}$ thiourea $^{6}$ ) and sulfanilamide ${ }^{7)}$ were also employed for this purpose, but these are not satisfactory in that they do not distribute uniformly throughout the body water. On the other hand the total body water can be calculated from the specific gravity of the body. ${ }^{8}$ ) However, the specific gravity method is labourious and is not easily applicable to patients.

In 1949 Soberman and his co-workers ${ }^{9}$ found that antipyrine satisfies the following conditions necessary for the measuremnt of total body water : (1) uniform and rapid distribution throughout the body water; (2) nontoxicity; (3) slow transformation and excretion; (4) accurate and convenient estimation of its concentration in plasma. So, they employed antipyrine for the measurement of the total body water in man, and showed 
that the results obtained by the volume of distribution of antipyrine agreed well with the body water content determined with heavy water.

The total body water in living subjects has been studied in American and Europeans. In this report it was estimated in normal subjects and edematous patients of Japanese by the antipyrine method of Soberman ${ }^{9}$, and the variation of the total body water in lean and obese subjects was examined.

\section{EXPERIMENTAL}

\section{Methods}

After a control sample of blood was drawn in postabsorptive state, $50 \mathrm{cc}$. of $2 \%$ (or $3 \%$ in edematous patients) antipyrine solution was injected intravenously. Blood samples were drawn at the 2nd, the 3rd and the 5 th hours (or at the 3 rd, the 4th and the 6 th hours) subsequently. The concentration of antipyrine in plasma was determined at the wavelength of $350 \mathrm{~m} / \mathrm{e}$ in a Beckman's spectrophotometer by the method of Brodie. ${ }^{10)}$ When the logarithm of the plasma concentration of antipyrine was plotted against time on semilogarithmic paper, the time-concentration curve yielded a straight line. The concentration at the time of injection was calculated by extrapolating this straight line back to zero time. The calculation of the total body water was made as follows :

$$
\text { Total body water }=\frac{\text { amount of antipyrine injected }}{\text { concentration of antipyrine in plasma }}
$$

\section{Results}

The total body water was determined in normal subjects and hospital patients clinically free from cardiovascular or renal disease, 12 males and 11 females, and in 17 edematous patients.

Normal subjects. As presented in Table $I$, the total body water of normal males averaged $32.6 \mathrm{l}$. (range 29.4 to $38.6 \mathrm{l}$.) or $56.4 \%$ of body weight (range 39.6 to $72.6 \%$ ), and as presented in Table II the total body water of normal females averaged $27.7 l$. (range 25.0 to $30.7 l$.) or $48.6 \%$ of body weight (range 35.0 to $61.3 \%$ ). Its percentage to body weight was higher in males than females, and showed a marked individual variability in both sexes: it was high in lean subjects and low in obese subjects. For example, the highest value of $72.6 \%$ was obtained in a very lean man (Height : $157.0 \mathrm{~cm}$., Weight : $43.0 \mathrm{~kg}$.) (No. 1 in Table I), and the lowest value of $35 \%$ in a very obese woman (Height: $154.5 \mathrm{~cm}$., Weight: 74.5 kg.) (No. 2 in Table II). This individual variability of body water is due to an inverse relationship of the percentage of body water to the percentage of body fat ${ }^{11}$ - the more the fat the less the water. Now, there 
TABLE I

Total Body Water in Normal Males

\begin{tabular}{|c|c|c|c|c|c|c|c|}
\hline $\begin{array}{l}\text { Subject } \\
\text { Number }\end{array}$ & $\begin{array}{l}\text { Age } \\
\text { year }\end{array}$ & $\begin{array}{l}\text { Height } \\
\text { cm. }\end{array}$ & $\begin{array}{l}\text { Body } \\
\text { weight } \\
\text { kg. }\end{array}$ & $\begin{array}{c}\text { Standard } \\
\text { body } \\
\text { weight } \\
\text { kg. }\end{array}$ & $\begin{array}{c}\text { Total } \\
\text { body water } \\
l .\end{array}$ & $\frac{\begin{array}{c}\text { Total } \\
\text { body water }\end{array}}{\text { Body weight }}$ & $\begin{array}{c}\text { Total } \\
\frac{\text { body water }}{\text { Standard }} \\
\text { body weight } \\
\%\end{array}$ \\
\hline No. 1 & 53 & 157.0 & 43.0 & 54.5 & 31.2 & 72.6 & 57.2 \\
\hline No. 2 & 29 & 162.0 & 49.5 & 56.7 & 30.6 & 61.8 & 54.0 \\
\hline No. 3 & 17 & 162.0 & 54.0 & 51.9 & 29.4 & 54.4 & 56.6 \\
\hline No. 4 & 40 & 161.5 & 53.7 & 57.3 & 31.8 & 59.2 & 55.5 \\
\hline No. 5 & 22 & 163.5 & 61.0 & 57.1 & 29.5 & 48.4 & 51.6 \\
\hline No. 6 & 58 & 168.0 & 86.2 & 61.9 & 34.1 & 39.6 & 55.1 \\
\hline No. 7 & 41 & 161.0 & 57.0 & 56.8 & 30.3 & 53.2 & 53.3 \\
\hline No. 8 & 34 & 175.0 & 62.0 & 65.0 & 38.6 & 62.3 & 59.4 \\
\hline No. 9 & 19 & 174.7 & 61.8 & 61.0 & 33.1 & 53.6 & 54.3 \\
\hline No. 10 & 34 & 168.4 & 53.1 & 60.8 & 34.2 & 64.5 & 56.3 \\
\hline No. 11 & 50 & 162.0 & 67.1 & 57.6 & 35.7 & 53.2 & 61.9 \\
\hline No. 12 & 22 & 165.2 & 61.3 & 58.0 & 33.6 & 54.8 & 57.9 \\
\hline \multicolumn{5}{|l|}{ Average } & 32.6 & 56.4 & 56.1 \\
\hline \multicolumn{5}{|l|}{ Range } & $29.4 \sim 38.6$ & $39.6 \sim 72.6$ & $51.6 \sim 61.9$ \\
\hline
\end{tabular}

must be a state of moderate nutrition, neither lean nor obese, for each individual - that is the standard body weight for his age and height. Since the percentage of the body water depends largely upon the body fat content as presented above, the body water expressed in the percentage of his standard body weight instead of his actual body weight for each individual will be considerably corrected in its individual variability. For this reason the body water was calculated in the percentage of the standard body weight for each individual, which was obtained from the standard age-height-weight table published by the Ministry of Welfare.12) As shown in the last column of Table I and II, its range contracted to between 51.6 and $61.9 \%$ in normal males, and to between 50.9 and $61.4 \%$ of the standard body weight in normal females, showing a far less conspicious variability than the percentage to their actual body weight. For example, the value of $72.6 \%$ of his actual body weight decreased to $57.2 \%$ of his standard body weight in the case No. 1 in Table I, and $35.0 \%$ increased to $50.9 \%$ of her standard body weight in the case No. 2 in Table II. Typical examples are illustrated in Fig. 1. The average of the percentage to their standard body weight was $56.1 \%$ in normal males and $55.0 \%$ in normal females (Tables I and II). It is interesting that the difference between the average of male and female becomes smaller by calculating 
TABLE II

Total Body Water in Normal Females

\begin{tabular}{|c|c|c|c|c|c|c|c|}
\hline $\begin{array}{l}\text { Subject } \\
\text { Number }\end{array}$ & $\begin{array}{l}\text { Age } \\
\text { year }\end{array}$ & $\begin{array}{l}\text { Height } \\
\text { cm. }\end{array}$ & $\begin{array}{l}\text { Body } \\
\text { weight } \\
\text { kg. }\end{array}$ & $\begin{array}{c}\text { Standard } \\
\text { body } \\
\text { weight } \\
\text { kg. }\end{array}$ & $\begin{array}{c}\text { Total } \\
\text { body water } \\
l .\end{array}$ & $\frac{\text { Total }}{\text { body water }}$ & $\begin{array}{c}\text { Total } \\
\text { body water } \\
\begin{array}{c}\text { Standard } \\
\text { body weight } \\
\%\end{array}\end{array}$ \\
\hline No. 1 & 35 & 145.5 & 52.8 & 47.8 & 25.1 & 47.5 & 52.5 \\
\hline No. 2 & 28 & 154.5 & 74.5 & 51.2 & 26.1 & 35.0 & 50.9 \\
\hline No. $3, \mathrm{a}$ & 35 & 152.0 & 74.0 & ${ }^{*} 50.7$ & 29.7 & 40.1 & 58.6 \\
\hline " $\quad b$ & $"$ & " & $* 58.6$ & $"$ & $* 26.4$ & $* 45.1$ & $* 52.1$ \\
\hline No. 4 & 17 & 155.4 & 47.8 & 48.8 & 25.0 & 52.3 & 51.2 \\
\hline No. 5 & 27 & 150.6 & 72.3 & 50.0 & 30.7 & 42.5 & 61.4 \\
\hline No. 6 & 19 & 160.0 & 54.2 & 52.1 & 27.8 & 51.3 & 53.4 \\
\hline No. 7 & 35 & 153.0 & 45.5 & 51.2 & 27.9 & 61.3 & 54.5 \\
\hline No. 8 & 19 & 164.5 & 53.4 & 56.2 & 30.5 & 57.1 & 54.3 \\
\hline No. 9 & 22 & 154.1 & 48.0 & 51.2 & 27.4 & 57.1 & 53.5 \\
\hline No. 10 & 19 & 153.0 & 77.0 & 50.3 & 29.4 & 38.2 & 58.4 \\
\hline No. 11 & 32 & 146.0 & 48.4 & 45.2 & 25.6 & 52.9 & 56.6 \\
\hline \multicolumn{5}{|l|}{ Average } & 27.7 & 48.6 & 55.0 \\
\hline \multicolumn{5}{|l|}{ Range } & $25.0 \sim 30.7$ & $35.0 \sim 61.3$ & $50.9 \sim 61.4$ \\
\hline
\end{tabular}

* Values obtained following decrease of body weight on a low calorie diet and by administration of thyrcoidin, and excluded in computing the average.

the percentage by the standard body weight than by the actual body weight. A very obese woman (Height: $152.0 \mathrm{~cm}$., Weight: $74.0 \mathrm{~kg}$.) (No. 3 in Table II) lost $15.4 \mathrm{~kg}$. in body weight on a low calorie diet and by administration of thyreoidin (a preparation of thyroid gland), but the reduction of body water was only $3.3 \mathrm{l}$. This indicates that body fat is greatly responsible for the variety of body weight in normal subjects.

Edematous patients. The results obtained with 17 edematous patients are summarized in Table III. The total body water averaged $40.2 \mathrm{l}$. (range 31.3 to $72.2 l$.) or $62.3 \%$ of body weight (range 56.8 to $73.6 \%$ ). It was higher on the average in edematous patients than in normal subjects. Individually speaking, however, the borderline between the edematous patients and the normal subjects was not obvious: not a few of patients had a lower value than lean normal subjects in spite of obvious edema. For example, 7 of 17 patients had values below $60 \%$ of their body weight. But, when the total body water was expressed by its percentage to their standard body weight, the edematous patients were clearly differentiated from the normal subjects: the total body water averaged $70.6 \%$ of the standard body weight (range 59.6 to $112.8 \%$ ) in edematous patients, 


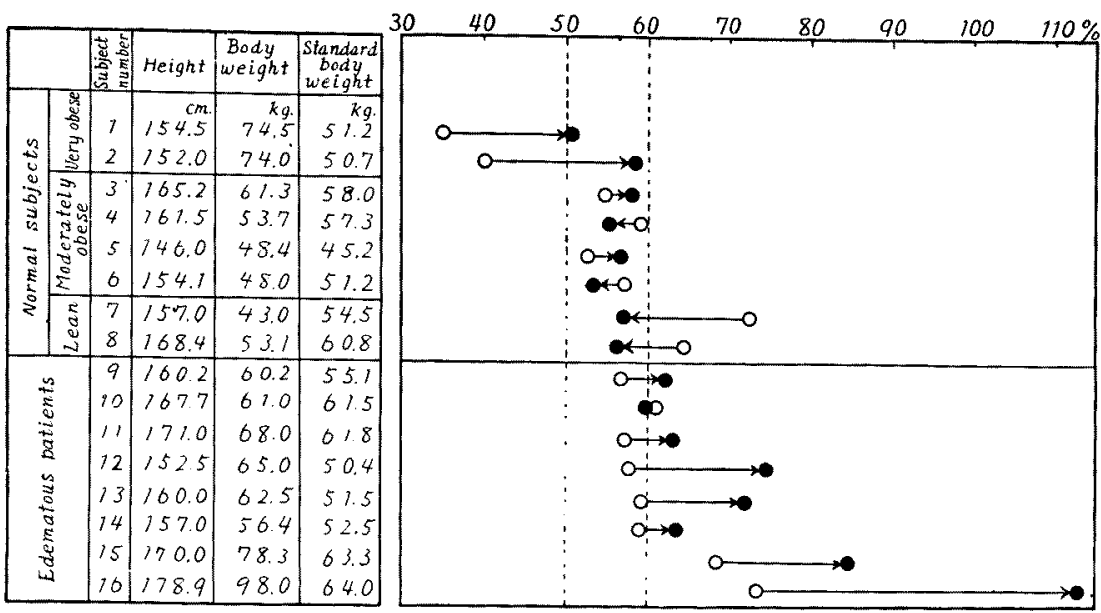

Fig. 1. Percentage of total body water to body weight $(O)$ and to standard body weight

exceeding $60 \%$ in most of them (the last column in Table III). Typical examples are illustrated in Fig. 1. In a markedly edematous patient of chronic nephritis with ascites (No. 16 in Table III) the total body water was $112.8 \%$ of the standard body weight. This value above $100 \%$ is not unreasonable because it only indicates that the weight of his total body water has increased beyond his standard body weight. In No. 5, 9 and 13 in Table III, who recovered from edema by treatment, the loss of body water $(12.8,8.1$ and $8.8 \mathrm{l}$.) was almost paralleled to the reduction of body weight $(14.0,10.5$ and $9.8 \mathrm{~kg}$.$) .$

\section{Discussion}

Since Hevesy ${ }^{4}$ first estimated the total body water in living man, it has been studied by other workers. The total body water as estimated by use of heavy water was reported to be $63 \%$ by Hevesy, to be $72.8 \%$ by Moore ${ }^{13)}$, to be $61.8 \%$ on the average (range 55.9 to $70.2 \%$ ) in normal males and $51.9 \%$ on the average (range 45.6 to $59.9 \%$ ) in normal females by Schloerb ${ }^{14)}$, and $60 \%$ of body weight on the average (range 42 to $71 \%$ ) in normal males by Hardy. ${ }^{15}$ ) On the other hand Soberman and his coworkers ${ }^{9)}$ employed antipyrine for the measurement of total body water and obtained a value of $54.5 \%$ of body weight on the average (range 50.4 to $57.9 \%$ ) in normal males, and they showed that the values agreed well with those obtained by heavy water method. Since then, the total body water estimated by antipyrine method was reported to be $53 \%$ on the average (range 40 to $68 \%$ ) in normal males and $45 \%$ on the average 
TABLE III

Total Body Water in Edematous Patients

\begin{tabular}{|c|c|c|c|c|c|c|c|c|c|}
\hline $\begin{array}{l}\text { Subject } \\
\text { Number }\end{array}$ & Diagnosis & 希 & 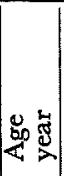 & 苟 & 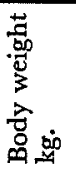 & 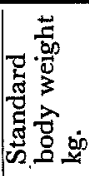 & $\begin{array}{c}\text { Total } \\
\text { body } \\
\text { water } \\
l .\end{array}$ & $\frac{\begin{array}{c}\text { Total } \\
\text { body water }\end{array}}{\underset{\%}{\text { Body weight }}}$ & $\begin{array}{c}\text { Total } \\
\text { body water } \\
\begin{array}{c}\text { Standard } \\
\text { body weight } \\
\%\end{array}\end{array}$ \\
\hline No. 1 & $\begin{array}{l}\text { Congestive } \\
\text { heart failure }\end{array}$ & $\mathbf{M}$ & 55 & 167.7 & 61.0 & 61.5 & 37.2 & 61.0 & 60.5 \\
\hline No. 2 & $"$ & $\mathbf{M}$ & 46 & 163.0 & 62.0 & 58.8 & 35.6 & 57.4 & 60.5 \\
\hline No. 3 & $"$ & $\mathbf{F}$ & 55 & 160.2 & 60.2 & 55.1 & 34.2 & 56.8 & 62.1 \\
\hline No. 4 & $"$ & $\mathbf{F}$ & 33 & 151.5 & 51.5 & 50.6 & 31.3 & 60.8 & 61.9 \\
\hline No. $5, \mathrm{a}$ & $"$ & F & 53 & 150.2 & 62.0 & 50.2 & 39.9 & 64.4 & 79.5 \\
\hline$" b$ & " & $"$ & $"$ & $"$ & $* 48.0$ & $"$ & $* 27.1$ & $* 56.5$ & $* 53.9$ \\
\hline No. 6 & Pericarditis & $\mathbf{M}$ & 60 & 170.0 & 78.3 & 63.3 & 53.6 & 68.4 & 84.6 \\
\hline No. 7 & $\begin{array}{l}\text { Chronic } \\
\text { nephritis }\end{array}$ & $\mathbf{M}$ & 19 & 160.2 & 68.5 & 57.5 & 48.8 & 71.2 & 84.8 \\
\hline No. 8 & " & $\mathbf{M}$ & 30 & 165.0 & 60.0 & 58.5 & 36.1 & 60.1 & 61.7 \\
\hline No. $9, \mathrm{a}$ & $"$ & $\mathbf{M}$ & 21 & 165.0 & 62.0 & 58.0 & 41.4 & 66.8 & 71.4 \\
\hline$" b$ & $"$ & $"$ & $"$ & $"$ & $* 51.5$ & $"$ & $* 33.3$ & $* 64.7$ & $* 57.4$ \\
\hline No. 10 & $"$ & $\mathbf{M}$ & 20 & 171.0 & 68.0 & 61.8 & 39.0 & 57.4 & 63.1 \\
\hline N0. 11 & $"$ & $\mathbf{M}$ & 25 & 167.0 & 61.3 & 59.2 & 35.6 & 58.1 & 60.1 \\
\hline No. 12 & Nephrosis & $F$ & 21 & 152.5 & 65.0 & 50.4 & 37.6 & 57.8 & 74.6 \\
\hline No. $13, a$ & $"$ & $\mathbf{M}$ & 17 & 160.0 & 62.5 & 51.5 & 37.1 & 59.4 & 72.0 \\
\hline$" b$ & Chronir & $"$ & $"$ & $"$ & $* 52.7$ & $"$ & $* 28.3$ & $* 53.7$ & $\approx 55.0$ \\
\hline No. 14 & $\begin{array}{l}\text { Chronic } \\
\text { nephritis }\end{array}$ & $\mathbf{M}$ & 26 & 159.9 & 53.4 & 55.5 & 33.1 & 61.9 & 59.6 \\
\hline No. 15 & $"$ & $\mathrm{M}$ & 35 & 160.1 & 58.0 & 55.9 & 37.9 & 65.3 & 67.7 \\
\hline No. 16 & $"$ & $\mathbf{M}$ & 22 & 178.9 & 98.0 & 64.0 & 72.2 & 73.6 & 112.8 \\
\hline No. 17 & $"$ & $\mathbf{F}$ & 26 & 157.0 & 56.4 & 52.5 & 33.4 & 59.2 & 63.6 \\
\hline \multicolumn{7}{|l|}{ Average } & 40.2 & 62.3 & 70.6 \\
\hline Range & & & & & & & $31.3 \sim 72.2$ & $56.8 \sim 73.6$ & $59.6 \sim 112.8$ \\
\hline
\end{tabular}

* Values obtained after disappearance of edema, and not included in computing the average.

(range 30 to $53 \%$ ) in normal females by Steele ${ }^{11)}$, and to be $61.1 \%$ of body weight on the average (range 43.0 to $72.9 \%$ ) in normal males by Osserman. ${ }^{16)}$ As presented above, the total body water ranges widely from about 30 to $70 \%$ of body weight, and its values obtained by these workers are not always in accord with one another in the average value. The total body water obtained in this study was $56.4 \%$ on the average (range 39.6 to $72.6 \%$ ) in normal males and $48.6 \%$ of body weight on the average (range 35.0 to $61.3 \%$ ) in normal females.

Behnke ${ }^{17)}$ estimated the specific gravity of the body in normal males, and Rathbun ${ }^{18)}$ devised a formula in experiments of animals, by which 
body fat can be calculated from the specific gravity of the body. Pace ${ }^{19}$ found that the body water occupies $72.4 \%$ of lean body mass or fat-free tissue. Applying this principle to the human body, Messinger $\left.{ }^{8}\right)$ and Osser$\operatorname{man}^{16)}$ calculated body fat by specific gravity method. Simultaneously they determined the total body water with antipyrine and they showed that the proportion of body water bears an inverse relationship to the proportion of body fat. From this finding it is easily understood that the percentage of the total body water to the body weight obtained in this study was high in lean subjects and low in obese subjects. The inconstancy in the results of estimation of the total body water obtained by other workers and the author is supposed to be due to the selection of subjects, but most of the average values in these results are below $60 \%$ of body weight. The generally used value of $70 \%$ of body weight ${ }^{1}$ is applicable only to very lean subjects such as No. 1 in Table I. In edematous patients the total body water and its percentage to body weight were higher on the average than in normal subjects. Individually speaking, however, edematous patients were not always differentiated from normal subjects in the percentage of the body water to the body weight. Steele ${ }^{11}$ also reported that not a few of markedly edematous patients fell within the normal range for body water, and he pointed out that measurement of the total body water alone is of little help in bringing to light abnormal accumulation of fluid because of the marked individual variability in the proportion of the body water.

At this point the percentage of the total body water to the standard body weight was proposed as a criterion for abnormal accumulation of body water in this study. Since the percentage of total body water to body weight depends largely upon fat content as stated above, the total body water expressed in the percentage to the standard body weight for each individual will be considerably corrected in its individual variability. In fact, the data presented here showed that the percentage of the total body water to the standard body weight in normal subjects was far less remarkable in its variability than its percentage to the actual body weight, and its range contracted to between 50 and $60 \%$ of the standard body weight. Soberman ${ }^{9}$ stated that an average man, neither lean nor obese, contains about $20 \%$ fat when body fat is calculated from the data of the body specific gravity of normal males obtained by Welham. ${ }^{201}$ The body water of an average man, calculated on the assumption that fat-free tissue contains $72.4 \%$ water, would be $58 \%$ of the body weight.

$$
(100-20) \times \frac{72.4}{100}=57.9 \%
$$

From the above data and considerations, about $60 \%$ of the standard body weight seems to be the upper limit of the body water in normal 
subjects, while the total body water exceeds $60 \%$ of their standard body weight in most of edematous patients. Thus, when the total body water is expressed in the percentage of the standard body weight, a line of demarcation can be drawn between normal subjects and edematous patients, which is not possible when the actual body weight is used in the estimation.

\section{SUMMARY}

1. The total body water was estimated by the antipyrine method in normal subjects and edematous patients.

2. The total body water averaged $56.4 \%$ (range 39.6 to $72.6 \%$ ) in 12 normal males, and averaged $48.6 \%$ of their body weight (range 35.0 to $61.3 \%$ ) in 11 normal females. It presented a remarkable individual variability: it was high in lean subjects and low in obese subjects.

3. Edematous patients were not always differentiated from normal subjects in the percentage of the total body water to their body weight. But a borderline can be drawn between normal subjects and edematous patients by expressing the total body water in the percentage to their standard body weight: About $60 \%$ of the standard body weight is the upper limit of the total body water in normal subjects, while the total body water exceeded $60 \%$ of the standard body weight in most of the edematous patients.

The expenses of this work were defrayed in part by a grant from the Education Department for Scientific Research.

F. Nakazawa

\section{References}

1) Gamble, Chemical Physiology and Pathology of Extracellular Fluid, Harvard University Press, Cambridge, 1952.

2) Bischoff, Ztschr. f. rat. Med., 1863, 20, 75.

3) Mitchell, Hamilton, Steggerda \& Bean, J. Biol. Chem., 1945, 158, 625.

4) Hevesy \& Hofer, Klin. Wschr., 1934, 13, 1524.

5) Winkler \& Smith, J. Biol. Chem., 1938, 124, 589.

6) Danowski, ibid., 1944, 152, 207.

7) Painter, Am. J. Physiol., 1940, 129, 744.

8) Messinger \& Steele, Proc. Soc. Exp. Biol. \& Med., 1949, 70, 316.

9) Soberman, Brodie, Levy, Axelrod, Hollander \& Steele, J: Biol. Chem., 1949, 179, 31.

10) Brodie, Axelrod, Soberman \& Levy, ibid., 1949, 179, 25.

11) Steele, Berger \& Brodie, Am. J. Physiol., 1950, 162, 313.

12) Koya, Koshueisei Gaku (Public Hygienics), Vol. 1, Nipponrinshosha Press, Tokyo, 1948, p. 354, Table 30.

13) Moore, Science, 1946, 104, 157. 1296.

14) Schloerb, Fritts-Hansen, Edelman, Solomon \& Moore, J. Clin. Invest., 1950, 29,

15) Hardy \& Drabkin, J.A.M.A., 1952, 149, 1113.

16) Osserman, Pitts, Welham \& Behnke, J. Applied Physiol., 1950, 2, 633. 
17) Behnke, Feen \& Welham, J.A.M.A., 1942, 118, 495.

18) Rathbun \& Pace, J. Biol. Chem., 1945, 158, 667.

19) Pace \& Rathbun, ibid., 1945, 158, 685.

20) Welham \& Behnke, J.A.M.A., 1942, 118, 498. 